J. Kyushu Dent. Soc. 54 ( 3 ) : 247 252, 2000.

\title{
Histogenesis of Oral Granular Cell Tumor: A Histopathological and Immunohistochemical Study
}

\author{
Hideo Kurokawa', Keiko Miura', Eiko Nakanishi², \\ Yoshihiro Yamashita', Futoshi Tabe', Min Zhang ${ }^{2}$ \\ and Hiroshi Fukuyama ${ }^{2}$ \\ ${ }^{1}$ Second Department of Oral Surgery (Acting Chief : Prof. Jinichi Fukuda) \\ ${ }^{2}$ Department of Oral Pathology (Chief: Prof. Hiroshi Fukuyama) \\ Kyushu Dental College, Kitakyushu, Japan
}

Accepted on April 25, 2000.

Granular cell tumor of the tongue in a 14-year-old girl is reported including details of studies using histopathology and immunohistochemistry. Histopathological examination revealed large tumor cells with eosinophilic, PAS positive fine granules under hyperplastic epithelium. Immunohistochemically, the tumor cells were positively stained for $\$-100$ protein. However, immunoreactivity for Neurofilament protein and Myoglobin was negative in the present case. These findings may indicate that this tumor is a lesion of Schwann cell origin.

Key words: Granular cell tumor/Tongue/Histogenesis/Immunohistochemical study

\section{Introduction}

Although granular cell tumor most frequently found in superficial soft tissue, this tumor is a relatively rare in oral cavity ${ }^{1,2)}$. There are some reports on histopathological, immunohistochemical, and ultrastructural studies of this tumor ${ }^{1-5)}$. However, its histogenesis and nature are still contraversial.

In this paper, the histogenesis of granular cell tumor was discussed based on the results of histopathological and immunohistochemical studies of the tumor appearing in oral cavity.

\section{Patient and Method}

A 14-year-old girl visited to our department with a chief complaint of a painless mass in the right side of the tongue. She had noticed a mass in the right side of the tongue for about 2 years, but neglected it because of the absence of subjective symptoms, such as pain. When she recently visited her private dentist to receive treatment for decayed teeth, she was advised to receive a complete examination and was referred to the clinic of oral surgery. On her first visit, laboratory tests and examination of her general condition showed no abnormality. 
Oral examination revealed a small finger-tip sized, well-defined, yellowishwhite, elastic hard mass in the right posterior portion on the tongue. The mass was a circular nodule measuring $10 \times$ $5 \mathrm{~mm}$. The suspected clinical diagnosis was benign tumor. Under general anesthesia, the tumor was resected together with the surrounding tissues as a mass. The postoperative course has been uneventful and no recurrence has occurred for about 2 years after the operation.

The removed specimen was a nodular, nearly oval-shaped tumor measuring $10 \times$ $5 \times 5 \mathrm{~mm}$. It was elastic and slightly hard. The cut surface was solid and yellowishwhite (Fig. 1).

Histopathology: The tissue specimens obtained by surgical excision were fixed $10 \%$ neutral formalin saline. The mass was cut into two parts and routine paraffin sections were made. Four micrometer-thick paraffin sections were cut and stained with hematoxylin-eosin (HE). Moreover, the Periodic Acid Shiff (PAS) reaction with and without diastase digestion was stained.

Immunohistochemistry: Deparaffinized sections were also prepared for immunohistchemistry. Primary antibodies against $\mathrm{S}-100$ protein (S-100), Neurofilament protein (NFP), and Myoglobin (MG) were purchased from DAKO (Glostrup, Denmark). For detection of the antigens, labelled streptavidin biotin (LSAB) method was used. The endogenous peroxidase activity was blocked with $3 \% \mathrm{H}_{2} \mathrm{O}_{2}$ for 5 minutes and the sections were incubated with normal cow serum for 5 minutes to reduce non-specific binding of antibodies. The sections for S-100 (dilution, $1: 200$ ), NFP (dilution, $1: 75$ ), and MG (dilution, $1: 200$ ) immunostaining were incubated for 20 minutes at room temperature. The second antibody was biotinylated mouse IgG, in which the sections were incubated for 10 minutes at room temperature. Peroxidase activity was developed using 3,3'-diaminobenzidine tetrahydrochloride (Sigma, Deistenhofen, Germany) substrate containing $0.3 \% \mathrm{H}_{2} \mathrm{O}_{2}$ for 20 minutes. Each step was followed by phosphate-buffer saline washing, and then lightly stained with Myer's hematoxylin. Negative controls consisted of a replacement of the primary antibody with non-immune serum. The immunohistochemical expression of S-100, NFP, and MG positivity 
was evaluated by a light microscopic study. When positive cells observed in the tissue specimen, it was considered to be a positive.

\section{Result}

Histopathogical findings: The tumor was covered by statified squamous epithelium showing pseudoepitheliomatous hyperplasia. The tumor had no capsule and extended into the muscle layer of the surrounding tissues. The tumor cells were oval, polygonal, and large. The cell borders were often unclear and syncytial formations were occasionally seen. The nuclei were round or ovoid in shape and contained one or two distinct nuclei but mitotic figures were not evident. The cytoplasma was filled with eosinophilic fine granules. These cytoplasmic granules were stained positively with PAS with resistance to diastase digestion. Striated muscle fibers were occasionally interspersed among the tumor cells, but did not transmigrate to the tumor cells (Fig. 2, 3).

Immunohistochemical findings: S-100 protein was moderately positive in the cytoplasma and nucleus of tumor cells. There was no immunoreactivity for NFP and MG in the tumor cells. The negative controls for each antibody showed no staining. (Fig. 4, 5).

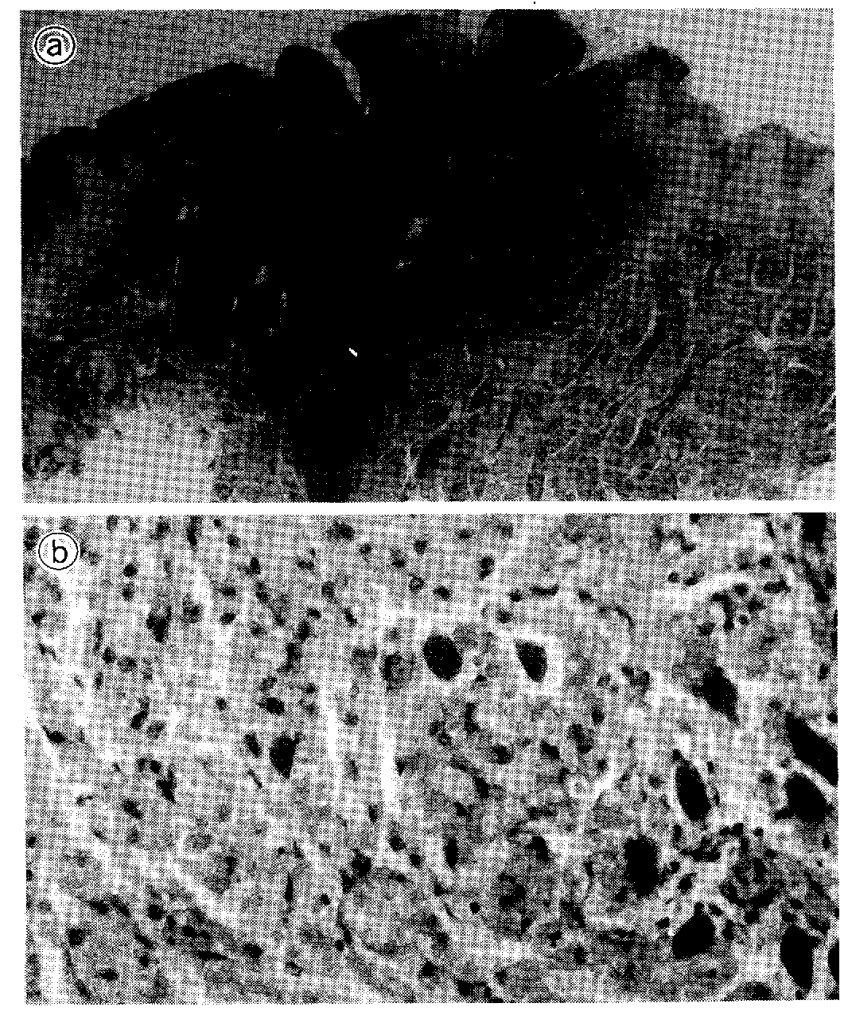

Fig. 2 The cytoplasma of tumor cell contained small eosinophilic granules (HE stain).

a: $\times 26$

b: $\times 263$
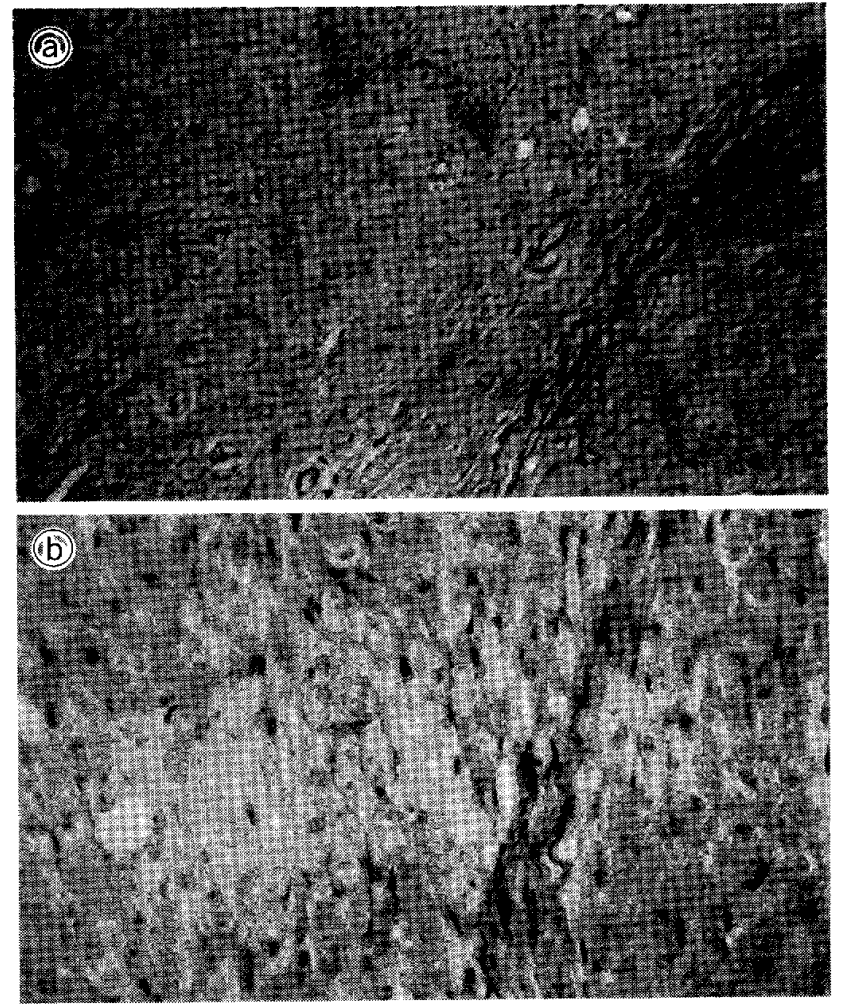

Fig. 3 The cytoplasmic granules stained positively with PAS reaction.

a: $\times 65$

b : $\times 130$ 

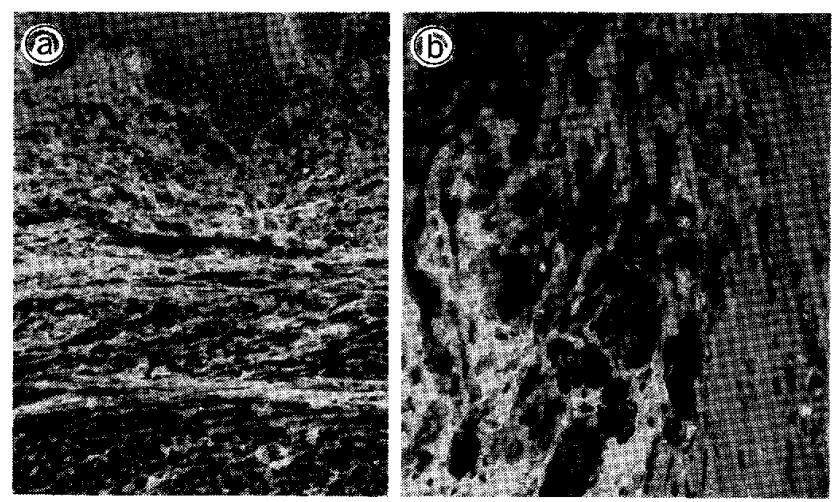

Fig. 4 The tumor cells shown staining for $\mathrm{S}-100$ protein.

a : $\times 42$

b : $\times 168$
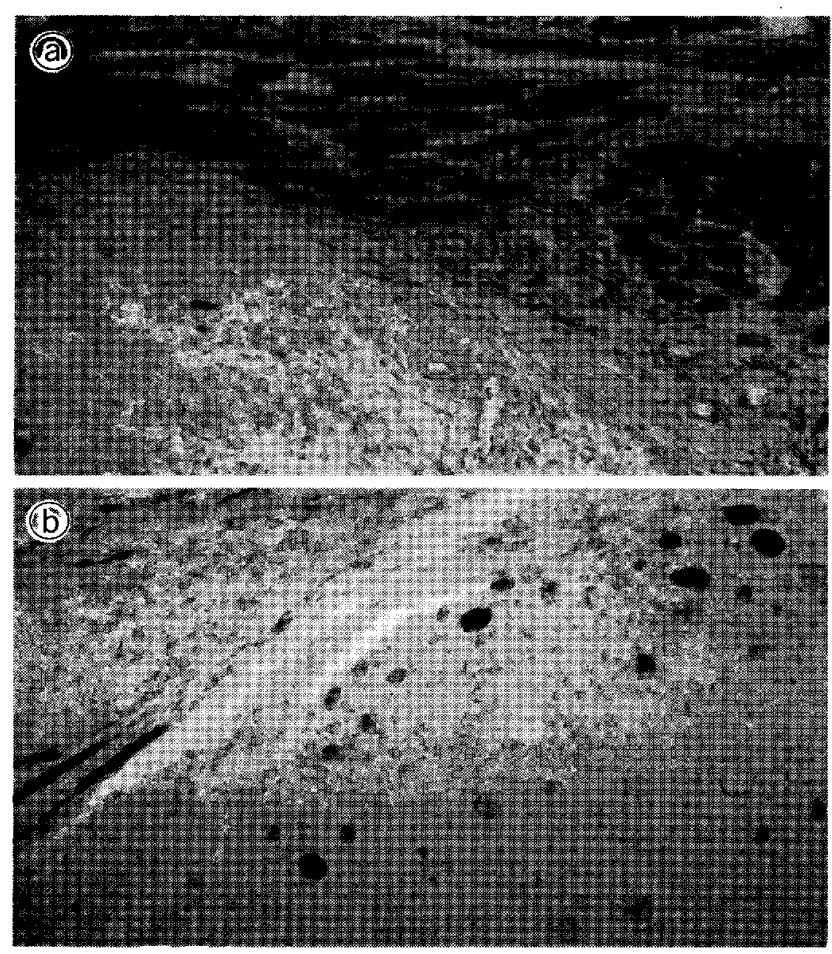

Fig. 5 The tumor cells stained negatively for Myoglobin. $\times 65$

\section{Discussion}

Granular cell tumor has first been described by Abrikossoff in 1926). Since then, many authors have reported in superficial soft tissue ${ }^{1,2)}$ and have discussed the histogenesis of this tumor ${ }^{2-5,7-9)}$. In the whole body, it often occurs in and under the skin ${ }^{1,2)}$. In the oral cavity, it has been reported to occur in the tongue, buccal mucosa, oral floor, palate, lower lip, and other tissues ${ }^{1-5)}$. Granular cell tumor in oral cavity occurs in very age group from newborn to elderly persons ${ }^{4,5)}$. This tumor has also been reported to occur more frequently in females with a ratio of about $3: 1^{4,5)}$. Since a painless mass formation is the only subjective symptom and no characteristic clinical symptoms are reduced by this tumor ${ }^{3,4}$, it is diagnosed on the basis of histopathological findings.

There are many theories concerning the origin of this tumor, such as myoblasts ${ }^{6}$, fibroblasts ${ }^{10)}$, histiocytes ${ }^{11)}$, epithelial cells ${ }^{12)}$, undifferentiated mesenchymal cells ${ }^{13)}$, neural cells ${ }^{14)}$, and various other cell types ${ }^{15}$. Although this tumor was classically thought to arise from myoblasts, immunohistochemical and ultrastructural investigations have suggested a neurogenic theory, especially Schwann cells ${ }^{16-18}$. Immunohistochemical studies of $\mathrm{S}-100$ protein, which is one of the specific neural proteins isolated from bovine brain, have been interpreted to favor the Schwann cell origin of granular cell tumor ${ }^{18)}$. S-100 protein is seen in the satellite Schwann cells among peripheral nerve tissues and tumor cells of nerve sheath origin $^{19)}$. In the present case, large tumor cells containing eosinophilic fine granules were 
stained positively with PAS stain and S-100 protein was positive in the tumor cells. However, neurofilament protein and myoglobin were absent in tumor cells. These findings of the presence in histopathological and immunohistochemical studies was thought to support the speculation that granular cell tumor in the present case might be derived from nerve cell (Schwann cell) precursor.

\section{Conclusion}

We examined the histogenesis of granular cell tumor based on the results of histopathological and immunohistochemical studies of the present case. On the basis our results, we consider that granular cell tumor in the present case may be derived from nerve cell (Schwann cell) precursor.

\section{Reference}

1) Nakamura, C., Kawakami, T., Hasegawa, H. and Eda, S.: Oral granular cell tumor: an electron microscopic and immunohistochemical study of two cases. Jpn. J. Oral Diag. Oral Med. 2: 220-226, 1989.

2) Okada, H., Yamamoto, H., Kawana, T., Katoh, T., Kozawa, Y. and Izumi, H.: Granular cell tumor of the tongue: an electron microscopical and immunohistochemical study. J. Nihon Univ. Sch. Dent. $32: 35-43,1990$.

3 ) Seki, N., Kameyama, T., Kihara, T., Yoshida, M., Hashimura, S., Fujimasa, T. and Okina, T.: A granular cell tumor of the buccal mucosa A case report-. Kurume Med. J. 40: 229-232, 1993.

4) Siar, C. H. and Han, K.: Unusual granular cell odontogenic tumor. Report of two undescribed cases with features of granular cell ameloblastoma and plexiform granular cell odontogenic tumor. J. Nihon Univ. Sch. Dent. 35: 134-138, 1993.

5) Kaiserling, E. Puck, P. and Xiao, J. C.: Congenital epulis and granular cell tumor. A histologic and immunohistochemical study. Oral Surg. Oral Med. Oral Pathol. 80:687-697, 1995.

6) Abrikossoff, A.: Uber Myome, ausgehend von quergestreifter willkurlicher Muskulatur. Virchows Archiv. A. 260: 215-233, 1926.

7 ) Fisher, E. and Wechsler, H.: Granular cell myoblastoma- a misnomer. Cancer 15: 936-954, 1962.

8 ) Garancis, J., Komorowski, R. A. and Kuzma, J. F.: Granular cell myoblastoma. Cancer 25: 542-550, 1970.

9) Armin, A., Connelly, E. M. and Rowden, G.: An immunoperoxidase investigation of S-100 protein in granular cell myoblastomas: evidence for Schwann cell derivation. Am. J. Clin. Pathol. 79: 37-44, 1983.

10) Pearse, A. G. E.: The histogenesis of granular cell myoblastoma (granular cell perineural fibroblastoma). J. Pathol. Bacteriol. 62: 351-362, 1950.

11) Azzopardi, J. G.: Histogenesis of granular cell myoblastoma. J. Pathol. Bacteriol. 71 : 85-94, 1956.

12) Gilliet, F., MacGee, W., Stoian, M. and Delacretaz, J.: Zur Histogenese granuliertzellinger Tumoren. Der. Hautarzt. 24:52-57, 1973.

13) Sobel, H. J., Schwarz, R. and Marquet, E.: Light and electron microscope study of the origin of granular cell myoblastoma. J. Pathol. 109: 101-111, 1973.

14) Sato, T., Asada, K., Ishibashi, K. and Sugawara, S.: A granular cell tumor of the floor of the mouth: immunohistochemical and electron microscopical observations. Jpn. J. Oral Maxillofac. Surg. 33 : 1548-1554, 1987.

15) Miller, A. S., Leifer, C., Chen, S. Y. and Harwick, R. D.: Oral granular cell tumors: Report of 
twenty-five cases with electron microscopy. Oral Surg. 44:227-237, 1977.

16) Mukai, M.: Immunohistochemical localization of S-100 protein and peripheral nerve myelin proteins in granular cell tumors. Am. J. Pathol. 112 : 139-146, 1983.

17) Bedetti, C. D., Martinez, A. J., Beckford, N. S. and May, M.: Granular cell tumor arising in myelinated peripheral nerves. Virchows Arch. Pathol. 402: 175-183, 1983.

18) Smolle, J., Konrad, K. and Kerl, H.: Granular cell tumors contain myelin-associated glycoprotein : An immunohistochemical study using Leu 7 monoclonal antibody. Virchows Arch. Pathol. 406: 1-5, 1985 .

19) Thompson, S. H.: myoblobrin content of granular cell tumor of the tongue: An immunoperoxidase study. Oral Surg. $57: 74-76,1984$.

\section{口腔領域における顆粒細胞腫の組織由来について： 病理組織学的ならびに免疫組織化学的研究}

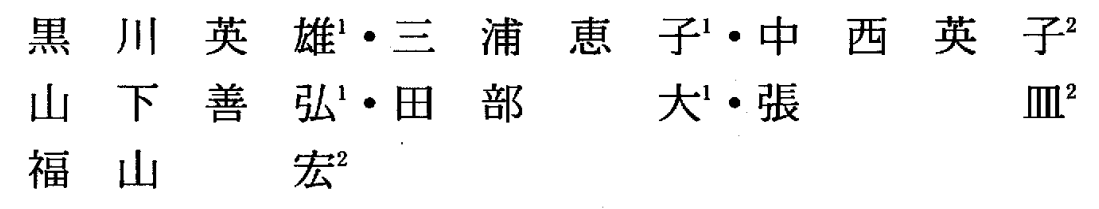

九州菊科大学口腔外科学第 2 講座 (主任代行：福田仁一教授) 九州歯科大学口腔病理学講座（主任：福山 宏教授）

14 歳, 女性の舌に発現した顆粒細胞腫について, 病理 組織学的ならびに免疫組織化学的研究を報告する，病理 組織学的には, 上皮下に好酸性で, PAS 陽性顆粒を含ん だ大型の腫瘍細胞が認められた。 また，免疫組織化学的
には, 腫瘍細胞は S-100 蛋白に陽性であったが, 神経繊 維蛋白やミオグロビン染色には陰性であった．以上のこ とから, 本腫瘍はシュワン細胞由来の病变であると思わ れた。 